\title{
Persuasão como instrumento de ação política na Atenas do século V a.C.: o caso de Péricles
}

\author{
The persuasion as an instrument of political action in 5th century \\ B.C. Athens: the case of Pericles
}

\author{
Ricardo Neves dos Santos*
}

Resumo: Na obra História da Guerra do Peloponeso, Tucídides afirma que Péricles, o eminente político ateniense, "podia conter a multidão sem Ihe ameaçar a liberdade, e conduzi-la ao invés de ser conduzido por ela, pois não recorria à adulação com o intuito de obter a força por meios menos dignos" (Thucydides, 2, 65, 8). Se Péricles não utilizava a imposição ou a adulação para governar seus concidadãos, qual era então seu principal instrumento de ação política? No presente artigo, trabalhar-se-á com a tese de que a persuasão foi o instrumento supremo utilizado por Péricles na condução de sua política entre os atenienses. Em meio à análise de trechos do terceiro discurso de Péricles, reportado por Tucídides (Thuc., 2, 60-4), serão apresentados quatro aspectos centrais de como isso se configurava.

\begin{abstract}
In the book History of the Peloponnesian War, Thucydides states that Pericles, the eminent Athenian politician, "could contain the crowd without threatening its freedom, and lead it instead of being led by it, as he did not resort to adulation to obtain strength by less worthy means" (Thuc., 2, 65, 8). If Pericles did not use imposition or adulation to govern his fellow citizens, what then was his main instrument of political action? In this article, we will defend the proposition that persuasion was the supreme instrument used by Pericles in conducting his policy among the Athenians. During the analysis of excerpts from Pericles' third speech reported by Thucydides (Thuc., 2, 60-4), four central aspects of how this was configured will be presented.
\end{abstract}

\author{
Palavras-chave: \\ Retórica. \\ Tucídides, \\ Péricles. \\ Historiografia antiga.
}

\author{
Keywords: \\ Rhetoric. \\ Thucydides. \\ Pericles. \\ Ancient historiography.
}

\footnotetext{
* Mestre em Letras Clássicas pela Universidade de São Paulo. Professor efetivo da rede municipal de ensino da cidade de São Paulo e associado à SBEC (Sociedade Brasileira de Estudos Clássicos). Também é membro do Grupo de Estudos sobre o Teatro Antigo (GTA/ USP) e do grupo de Estudos sobre Retórica e Argumentação (GERAR/USP).
} 


\section{Considerações preliminares ${ }^{1}$}

$\mathrm{N}$ a obra História da Guerra do Peloponeso, Tucídides faz a seguinte descrição de Péricles, o eminente político ateniense: "Ele podia conter a multidão sem lhe ameaçar a liberdade, e conduzi-la ao invés de ser conduzido por ela, pois não recorria à adulação com o intuito de obter a força por meios menos dignos" (Thuc., 2, $65,8) .^{2}$

A passagem citada fomenta uma questão difícil de ser respondida, mas relevante para se entender aspectos da política interna da Atenas na época da Guerra do Peloponeso: se Péricles não utilizava a imposição ou a adulação para governar seus concidadãos, qual era então seu principal instrumento de ação política? ${ }^{3}$

No presente artigo, trabalhar-se-á com a tese de que a persuasão foi o instrumento supremo utilizado por Péricles na condução de sua política entre os atenienses. Por meio da análise de trechos do terceiro discurso de Péricles, reportado por Tucídides $(2,60-4)$, na obra História da Guerra do Peloponeso, serão apresentados quatro aspectos centrais de como isso se configurava.

Segundo Jean Pierre Vernant (2002, p. 53), o aparecimento da pólis constituiu um acontecimento decisivo na história do pensamento grego. Desde seu advento, entre os séculos VIII e VII a.C., seu sistema geralmente implicava uma extraordinária preeminência da palavra sobre todos os outros instrumentos de poder, e não seria estapafúrdio dizer que a Atenas do século V a.C. figurou o apogeu desse fenômeno. ${ }^{4} \mathrm{Na}$ cidade de Atenas, a oratória tornou-se o instrumento de ação política por excelência, o principal meio de comando. A livre adesão às teses propostas por um orador eloquente foi chamada pelos

\footnotetext{
${ }^{1}$ Dedico o presente artigo à memória da Professora Doutora Lineide do Lago Salvador Mosca (1941-2021), fundadora do Grupo de Estudos sobre Retórica e Argumentação da Universidade de São Paulo (Gerar/ Usp).

${ }^{2}$ A tradução da História da Guerra do Peloponeso que será utilizada na análise proposta é a de Mário da Gama Kury (1982).

${ }^{3}$ Péricles passou a ser o principal líder da democracia ateniense depois do exílio de Címon e da morte de Efialtes por volta dos anos 460 a.C. Os magistrados em Atenas eram escolhidos por meio de sorteio. Porém, o ocupante do posto de estratego (general) era escolhido por meio de eleições. Péricles foi escolhido quinze vezes consecutivas como estratego pelos atenienses, ocupando tal posto até a sua morte, em 429 a. C. (RIBEIRO FERREIRA, 1990; MOSSÉ, 1985). 4 A pólis, muitas vezes traduzida pela expressão "cidade-Estado", tem o seu surgimento relacionado com o fim do Período Micênico. A vida em sociedade entre os gregos passou a se reestruturar principalmente em centros urbanos autônomos. Neles, notava-se geralmente uma área alta, denominada acrópole, na qual eram construídos os templos. Também havia a ágora, construída em área baixa e plana, na qual a convivência era mais efervescente, com o seu respectivo mercado e suas construções públicas ao redor. Mais distantes da acrópole e da ágora ficavam os campos cultiváveis. Apesar das diferenças políticas existentes entre as pólis, comumente em cada uma delas existia uma assembleia formada pelo corpo de cidadãos (Ekklesía), que se reunia na ágora, e também conselhos aristocráticos, os quais recebiam nomes diferentes dependendo da região. As principais diferenças políticas entre as pólis se operava no grau de poder que as respectivas assembleias populares detinham em relação às aristocracias locais. No caso de Atenas, as decisões mais importantes referentes à polis eram tomadas na Ekklesía, na qual todo cidadão tinha o direito de dar a sua contribuição tomando a palavra (AUSTIN; NAQUET, 1986).
} 
gregos de persuasão (peithó). Tudo aquilo que antes cabia ao tirano decidir passou a ser submetido à arte oratória dentro da pólis, permeando as demonstrações antitéticas em suas instituições, os confrontos orais de razões opostas, as resoluções advindas dos debates acirrados. Tal dinâmica só era possível devido à manutenção do que os gregos chamavam de parresía, isto é, a liberdade de expressar em público a própria opinião com franqueza. Viu-se, então, o advento da figura do rhétor ("orador"), termo que inicialmente designava qualquer cidadão que se prontificasse a se dirigir à assembleia de cidadãos (Ekklesía) e apresentar uma proposta ou apenas contribuir com o debate. Posteriormente, o termo rhétor foi evoluindo para designar mais especificamente os cidadãos que se destacavam no uso da palavra, influenciando o rumo das decisões dentro da pólis, e tornando-se, por isso, líderes reconhecidos pela maioria. Dessa forma, rhétor passou a significar «político» (YUNIS, 1996, p. 10). Com a crescente percepção de que o poder repousava cada vez mais sobre aquele que detinha o uso persuasivo da linguagem, começaram então a surgir professores de eloquência no seio das principais pólis, sobretudo nas que gozavam de regime democrático. Muitos desses mestres eram denominados também pelo termo rhétor (Platão, Gorgias, 457 a-c) ${ }^{5}$

Será que Péricles poderia ser considerado um rhétor? Sim, pelo menos no sentido "político" do termo. Mas não na acepção de "professor de eloquência", a não ser figuradamente, pois seus recursos financeiros não eram advindos da atividade de ensino, mas sim de sua liderança entre os atenienses como orador e estratego. Inclusive Plutarco afirma que Péricles descendia de uma família aristocrática e rica (Plutarco, Pericles, 3, 1). No Górgias, de Platão, por exemplo, Sócrates pergunta ao personagem Cálicles se porventura conhecia algum rhétor que, por meio dos seus belos discursos, teria contribuído para tornar os cidadãos atenienses melhores. Cálicles, por sua vez, responde: "E então? Não ouves que Temístocles fora um bom homem, além de Címon, Milcíades e Péricles, o qual morreu recentemente e cujos discursos também tu ouviste?" (Plat., Gorg., 503 b-c). ${ }^{6}$ No diálogo Simpósio (215 e), também de Platão, o personagem Alcibíades menciona o nome de Péricles ao lado dos "bons oradores" (agathón rhetóron).

Segundo Christian Plantin (2018, p.251), é comum que a palavra grega peithó seja traduzida por "persuasão" ou "convencimento" de maneira indistinta em muitas versões modernas dos textos clássicos. Mas Perelman e Olbrechts-Tyteca (1996, p. 22; 35) entendem que a distinção entre "persuadir" e "convencer" seria estabelecida na base de uma hierarquização dos auditórios, ou seja, "persuasiva" seria uma argumentação que

\footnotetext{
${ }^{5}$ A palavra rhétor ("orador") faz parte do mesmo campo semântico das palavras gregas rhéma ("dito", "palavra", "discurso"), rhésis ("declaração", "citação"), rhétra ("conversação", "convenção", "acordo"). (LIDDEL; SCOTT, 1996).

${ }^{6}$ Todos os trechos citados do Górgias, de Platão são da tradução feita por Daniel R. N. Lopes (2016).
} 
pretendesse ter validade para um auditório particular, e "convincente" a argumentação que supostamente fosse válida a todo ser racional, como ocorreria, pelo menos em tese, no discurso científico. Nada obstante, o que também parece distinguir os termos "persuasão" e "convencimento" é que a "persuasão", como processo argumentativo, não é vista apenas como um simples estado mental, como uma "adesão do espírito". Ainda segundo Plantin (2018, p. 256), "o último critério da persuasão completa é a ação cumprida no sentido sugerido pelo discurso, e a emoção cumpre um papel essencial nessa passagem ao ato". Levando-se isso em conta, percebe-se que a abordagem do orador é, por assim dizer, multidisciplinar; pois respeitar a capacidade de julgamento do ouvinte, levando em conta os aspectos lógicos de seu pensamento, bem como aspectos intuitivos e emocionais, são condições imprescindíveis para que a persuasão ocorra. Todavia, tais procedimentos não garantem infalivelmente a efetivação da persuasão, posto que, numa verdadeira interação argumentativa, respeita-se sempre a liberdade de julgamento e de decisão do outro.

É por isso que Aristóteles, na obra Retórica (1355 b), afirma que o orador não possui um poder absoluto de persuadir. É de sua competência, porém, discernir os meios de persuasão mais adequados em cada caso, tal como acontece entre os médicos, "pois não é função da medicina dar saúde ao doente", diz Aristóteles, "mas avançar o mais possível na direção da cura, pois também se pode cuidar bem dos que já não estão em condições de recuperar a saúde". 7 Subentende-se, então, que independentemente do esforço do orador, a persuasão é uma dádiva ofertada pelo ouvinte. E, de fato, a argumentação só é possível quando não se trata o outro como um simples objeto (PERELMAN; OLBRECHTSTYTECA, 1996, p. 525). No Tratado da Argumentação, Perelman e Olbrechts-Tyteca (1996, p. 581) reiteram que a liberdade de decisão e de julgamento é um elemento imprescindível em todo ato argumentativo:

Se a liberdade fosse apenas adesão necessária a uma ordem natural dada, excluiria qualquer possibilidade de escolha; se o exercício da liberdade não fosse fundamentado em razões, toda escolha seria irracional e se reduziria a uma decisão arbitrária atuando num vazio intelectual. Graças à possibilidade de uma argumentação que forneça razões, mas razões não-coercitivas, é que é possível escapar ao dilema: adesão a uma verdade objetiva e universalmente válida, ou recurso à sugestão e à violência para fazer que se admitam suas opiniões e decisões.

É justamente o recurso à argumentação que distingue a persuasão da simples manipulação, e também a distingue da coerção, que se vale da violência (PERELMAN; OLBRECHTS-TYTECA, 1996, p. 61).

\footnotetext{
${ }^{7}$ Ao logo da discussão, será utilizada a tradução da Retórica de Aristóteles feita por Manuel Alexandre Júnior, Paulo Farmhouse Alberto e Abel do Nascimento Pena (1998).
} 
Levando-se em conta o testemunho de Tucídides citado no início deste artigo (Thuc., 2, 65, 8), perceberemos que Péricles se dispunha a argumentar ao invés de se valer de uma atitude coercitiva em sua interação com os cidadãos; algo que não ocorria na política externa adotada por Atenas em relação às outras pólis (COHEN, 1984, p. 48; MANUWALD, 2009, p. 248).

Isso posto, seria profícuo descrever sucintamente as circunstâncias e os fatores envolvidos na realização do discurso proferido pelo político ateniense, o qual será analisado mais adiante.

Segundo Tucídides (1, 145), Péricles persuadira os atenienses a entrar numa guerra contra Esparta. Confiando em maiores recursos financeiros e na poderosa marinha de sua pólis (Thuc., 1, 141), o general ateniense concebeu a estratégia de evitar confrontos terrestres quando as forças inimigas invadissem o território da Ática. Enquanto isso, a marinha de Atenas enfraqueceria o inimigo por meio de incursões devastadoras (Thuc., 1, 143). Péricles aconselhava seus concidadãos a focarem seus esforços nessa estratégia, sem se preocupar em aumentar o império ateniense enquanto não vencesse o inimigo por completo, o que seria inevitável, segundo seus cálculos (Thuc., 1, 144). No entanto, os refugiados da Ática invadida procuraram abrigo na cidade de Atenas (Thuc., 2, 14). Aglomerados humanos formaram-se, casas ficaram lotadas e o excedente foi alojado em cabanas e barracas improvisadas ao longo dos muros que iam até o Pireu, principal porto de Atenas (Thuc., 2, 17). Criou-se, assim, um terreno propício para a disseminação de epidemias, e como consequência a chamada "Peste de Atenas" despontou (Thuc., 2, 47-54), fazendo a balança pender contra os atenienses na guerra (LIDDELL HART, 1982, p. 34). Tucídides afirma que as consequências da peste foram nefastas:

De um modo geral a peste introduziu na cidade pela primeira vez a anarquia total. Ousava-se com a maior naturalidade e abertamente aquilo que antes só se fazia ocultamente, vendo-se quão rapidamente mudava a sorte, tanto a dos homens ricos subitamente mortos quanto a daqueles que antes nada tinham e num momento se tornavam dono dos bens alheios. Todos resolveram gozar o mais depressa possível os prazeres que a existência ainda pudesse proporcionar, e assim satisfaziam os seus caprichos, vendo que suas vidas e riquezas eram efêmeras. [...] Censuravam Péricles por havê-los persuadido a entrar na guerra e o responsabilizavam por todos os seus infortúnios [...]. Sentindo-se no limite de seu desespero, intensificavam suas acusações contra Péricles (Thuc., 2, 53-9).

O estado de anarquia ocasionado pela peste em Atenas também pode ser relacionado com o termo grego stásis, empregado muitas vezes por Tucídides para se referir às guerras civis ocasionadas durante o grande conflito entre as cidades-Estados gregas, como a ocorrida em Corcira (Thuc., 3, 69-85). Tal estado (stásis), valendo-se de 
uma imagem cunhada pelo próprio Tucídides, seria uma espécie de "espiral do mal", que ia envolvendo e destruindo a todos (Thuc., 3, 83, 1).

Contudo, Péricles não se acanha diante de tão grande calamidade. Convoca uma assembleia e profere um discurso que produz os seguintes efeitos:

Dizendo estas palavras, Péricles procurou afastar os atenienses do ressentimento e distrair-lhes os espíritos de seus males do momento. Quantos aos problemas de ordem pública, conseguiu convencê-los com seus argumentos. [...] Não muito tempo depois, numa reviravolta muito ao gosto das multidões, os atenienses o reelegeram comandante e Ihe confiaram a condução de todos os assuntos da cidade (Thuc., 2, 65, 1-5).

Mesmo em circunstâncias tão adversas, quais seriam as condições necessárias para se valer da persuasão como principal instrumento de ação política? Como Péricles as percebeu e as utilizou? Nas páginas a seguir, pretende-se entender as possíveis causas de tamanho êxito de Péricles. Antes, porém, é preciso fazer uma ressalva acerca do registro que Tucídides fez do discurso em foco.

\section{O Péricles tucididiano}

Evidentemente, o relato de Tucídides não é a expressão inequívoca do que realmente aconteceu. Isso de fato é impossível, principalmente levando-se em conta os meios técnicos que ele tinha à mão e a própria limitação humana (YUNIS, 1996, p. 612). Ele mesmo menciona tais dificuldades nos seus famosos "parágrafos metodológicos" (Thuc., 1, 20-3):

Quanto aos discursos pronunciados por diversas personalidades quando estavam prestes a desencadear a guerra ou quando já estavam engajados nela, foi difícil recordar com precisão rigorosa os que eu mesmo ouvi ou os que me foram transmitidos por várias fontes. Tais discursos, portanto, são reproduzidos com as palavras que, no meu entendimento, os diferentes oradores deveriam ter usado, considerando os respectivos assuntos e os sentimentos mais pertinentes à ocasião em que foram pronunciados, embora ao mesmo tempo eu tenha aderido tão estritamente quanto possível ao sentido geral do que havia sido dito (Thuc., $1,22,1)$.

Cinco séculos mais tarde, Plutarco também menciona algumas das dificuldades que ele próprio encontrou quando se dispôs a escrever uma biografia de Péricles:

Assim parece ser penoso e difícil a quem investiga encontrar a verdade: os que vêm depois têm o tempo decorrido a obscurecer o conhecimento dos factos; por seu lado a contemporaneidade com os acontecimentos e com as vidas corrompe 
e distorce a verdade ora por invejas e hostilidades, ora por favores e adulações (Plut., Per., 13, 14). ${ }^{8}$

Segundo Soares (2011, p. 2), historiadores gregos como Heródoto e Tucídides compensavam as limitações supramencionadas por meio do hábito de conferir assertividade e autoridade às suas narrativas históricas, insuflando-Ihes vividez pictórica, de modo a gerar impacto emocional e visual na mente dos leitores. Esse processo era frequentemente designado pelo termo enargeia (vividez), fundamental na composição da ekphrasis (descrição). Soares ainda afirma que um historiador, no sentido grego do termo (histor), era aquele que via e fazia ver. E de fato, "fazer ver era, na verdade, a qualidade mais importante do histor na Grécia antiga. Mais do que ter visto, o histor devia fazer ver" (SOARES, 2011, p.5). Essa concepção antiga de historiador não foi abandonada de todo, pois sabe-se que mesmo a historiografia moderna possui uma dimensão narrativa inalienável, tendo um potencial descritivo que torna os acontecimentos do passado "visíveis" aos leitores (SOARES, 2011, p. 19).

Nota-se, portanto, que a dimensão narrativa é um importante ponto de intersecção entre história e ficção. No entanto, o filósofo francês Paul Ricœur (1985, p. 154) assevera que só a historiografia pode reivindicar uma referência que se inscreve no empírico, na medida em que a intencionalidade histórica se dirige a fatos que realmente aconteceram. Mesmo que o passado já não exista e se, valendo-se de uma expressão de Santo Agostinho (Confessiones, 11, 15), ele só pode ser alcançado no presente do passado, ou seja, através dos vestígios do passado, que se tornaram documentos para o historiador, permanece o fato de que o passado aconteceu. $\mathrm{O}$ acontecimento passado, por mais ausente que esteja à percepção presente, governa a intencionalidade histórica, dando-lhe uma nota factual que nenhuma literatura jamais igualará, mesmo que pretenda ser «realista».

A discussão sobre as fronteiras entre história e ficção é de longa data. No capítulo IX da obra Arte Poética, Aristóteles faz a distinção entre o texto ficcional (poético) e o historiográfico, afirmando que este "narra as coisas que aconteceram, e aquele narra as coisas que poderiam acontecer" (Arist., Poet., 1451 b). Talvez a afirmação de Aristóteles de que a poesia "narra as coisa que poderiam acontecer" soe estranha aos ouvidos modernos. Mas sua afirmação reflete uma visão de mundo que provavelmente não esteja tão em voga atualmente, isto é, a de que a poesia é capaz de servir de paradigma às pessoas. Aristóteles procura justificar sua afirmação dizendo que a poesia, assim como a filosofia, visa ao "universal", ou seja, àquilo que é atemporal, não transitório e, por isso mesmo,

${ }^{8}$ Os trechos utilizados da obra Vidas Paralelas - Péricles e Fábio Máximo, de Plutarco, são da tradução realizada por Ana Maria Guedes Ferreira e Ália Rosa Conceição Rodrigues (2013). 
paradigmático e referencial. A história, por outro lado, ao particular, ao idiossincrático (SANTOS, 2020, p. 176). Nesse sentido, o papel da história seria apenas descrever e registrar os fatos. Quando, a partir desses registros, procura-se tirar lições e cogitar sobre o futuro, abandona-se a postura de historiador, e assume-se o papel de filósofo ou poeta, pelo menos segundo a concepção de Aristóteles. O sábio estagirita ainda assevera:

Com efeito, não diferem o historiador e o poeta por escreverem verso ou prosa (pois que bem poderiam ser postos em verso as obras de Heródoto, e nem por isso deixariam de ser história, se fossem em verso o que eram em prosa - diferem, sim, em que um diz as coisas que sucederam, e outro as que poderiam suceder (Arist., Poet., 1451a-b). ${ }^{9}$

Sabe-se que a distinção entre história e ficção feita por Aristóteles é posterior à obra de Tucídides. E o historiador ateniense, embora declaradamente se diferencie dos poetas de seu tempo (Thuc., 1, 22), não deixa por isso de alegar certo valor universal à História da Guerra do Peloponeso, afirmando que seu relato soaria menos agradável aos ouvidos, mas para quem desejasse ter uma ideia clara "tanto dos eventos ocorridos quanto daqueles que algum dia voltariam a ocorrer em circunstâncias idênticas ou semelhantes em consequência de seu conteúdo humano (anthrópinon)", julgaria a sua obra útil e isso Ihe bastaria. Tucídides também afirma: "Na verdade, ela foi feita para ser um patrimônio sempre útil, e não uma composição a ser ouvida apenas no momento da competição por algum prêmio" (Thuc., 1, 22). O historiador ateniense também não se priva de refletir, diante dos fatos consumados, o que poderia ter acontecido se as escolhas de seus contemporâneos fossem diferentes (Thuc., 2, 66).

Para Rusten (2004, p. 21), Tucídides dá a Péricles um caráter dinâmico que transcende seu fundamento histórico factual. Ele o priva, por exemplo, de muito de sua carreira e personalidade, mas Ihe concede universalidade, "a única coisa que Aristóteles diz que a história não pode fornecer". Em tal relato, não se apreende o que Péricles realmente fez ou o que aconteceu com ele, "mas os tipos de insights e argumentos sobre política, sociedade humana e poder, que permeiam qualquer época, mesmo a nossa, e pode valer a pena repeti-los continuamente".

Quanto aos discursos encontrados na História da Guerra do Peloponeso, é fácil perceber que eles não se adequam completamente à definição dada por Aristóteles ao texto "historiográfico", mas ocupariam um lugar entre "o que aconteceu" (história) e "o que poderia acontecer" (poesia). Pois os discursos foram registrados "como deveriam ter acontecido". Ele mesmo afirma que "tais discursos, portanto, são reproduzidos com as

\footnotetext{
${ }^{9}$ Tradução de Eudoro de Souza (1973).
} 
palavras que, no meu entendimento, os diferentes oradores deveriam ter usado" (Thuc., $1,22,1$, grifo nosso). Posto isso, propõe-se o seguinte esquema de entendimento acerca dos discursos:

- História: o que aconteceu (segundo Aristóteles)

- Discursos de Tucídides: o que deveria ter acontecido (a proposta aqui adotada)

- Poesia (ficção): o que poderia acontecer (segundo Aristóteles)

Reiteramos, portanto: embora se tenha aqui o objetivo de analisar um dos discursos atribuídos a Péricles por Tucídides, não se acredita, porém, que tal discurso seja uma representação ipsis litteris do que o político ateniense pronunciou, e o mesmo vale para os demais discursos encontrados na obra. Muitas vezes pode-se notar neles a mesma linguagem densa e peculiar de Tucídides, também perceptível nas partes narrativas (YUNIS, 1996, p. 62). Também é interessante notar que Aristóteles (Rh., livro III, 1411 a) atribuiu a seguinte afirmação a Péricles: "Assim como se extraísse a primavera do ano, a juventude morta na guerra fora arrebatada à cidade". Porém, não se encontra tal analogia na oração fúnebre reportada por Tucídides e atribuída a Péricles (Thuc., 2, 35-46). Vale ainda salientar que a visão de Tucídides em relação a Péricles é bastante otimista em comparação com a opinião de alguns de seus contemporâneos, como o poeta cômico Aristófanes e o filósofo Platão (RUSTEN, 2004, p. 10-1). O Sócrates platônico, por exemplo, afirma o seguinte acerca de Péricles (Plat., Gorg., 515 e):

Mas dize-me, o que se fala dos atenienses: eles se tornaram melhores por causa de Péricles, ou, pelo contrário, foram por ele corrompidos? Pois pelo menos eu tenho escutado que Péricles tornou os atenienses preguiçosos, covardes, tagarelas e avarentos, quando instituiu ineditamente as recompensas. ${ }^{10}$

Uma das teses em jogo no diálogo citado é a de que o bom político (rhétor), por meio dos seus discursos, poderia tornar seus concidadãos melhores. Visto que os atenienses se tornaram piores depois das intervenções de Péricles, segundo Sócrates, então o estratego não poderia ter sido um bom político. Aristófanes, por sua vez, insinuou que a guerra entre os gregos começou devido à atitude vingativa de Péricles, que teria retaliado os megarenses por raptarem duas cortesãs que trabalhavam para Aspásia, amante do estadista (Acharnenses, 524-527). Embora a opinião de Aristófanes seja semelhante à de Tucídides quanto ao político ateniense Cleão, considerado prejudicial à pólis ateniense por

\footnotetext{
${ }^{10}$ Na Política, Aristóteles afirma que Péricles instituiu o pagamento diário de dois óbolos para cada cidadão que exercesse a função de juiz nos tribunais de Atenas. Posteriormente o valor foi aumentado para três óbolos.
} 
ambos, diferem em relação a Péricles. E de fato, as piadas de Aristófanes não pouparam a política externa defendida pelo estratego (Nubes, 858-859; Ach., 515-539; Pax, 601-611). Tucídides, porém, entendia que a estratégia de guerra desenhada por Péricles era correta e que os atenienses erraram em não a manter depois da morte do político, ocorrida no outono de 429 a.C.

Diferentemente de Aristófanes e Platão, e mais próximo da opinião de Tucídides, o poeta cômico Êupolis, que costumava atacar políticos como Alcibíades e Hipérbolo impiedosamente, escreveu uma peça chamada Demos, na qual invoca os grandes líderes do passado de Atenas, suplicando-lhes que salvassem a cidade num momento de crise. Êupolis escolheu um líder de cada geração: Sólon, da Atenas arcaica; Miltíades, de Maratona; Aristides, de Salamina; e finalmente Péricles. Ou seja, mesmo poucos anos depois de sua morte, enquanto o problema da guerra perdurava, Péricles fora mencionado entre os grandes líderes de Atenas por esse poeta cômico não tão conhecido atualmente (RUSTEN, 2004, p.11). Ainda segundo Rusten (2004, p. 11), a biografia de Péricles escrita por Plutarco é menos tendenciosa e mais diversa do que qualquer outro relato, apesar de estar afastada cerca de quinhentos anos dos fatos.

A despeito das divergências em relação à descrição de Péricles, nem por isso a História da Guerra do Peloponeso perde o seu valor "historiográfico" (RAAFLAUB, 2013, p. 5; 8), pois entre a total ignorância dos fatos ocorridos e a contemplação absoluta da verdade, ou realidade, temos o relato de Tucídides à mão; o qual nos possibilitará ter alguma noção, mesmo que seja apenas sombra, da eloquência real que Péricles possuiu (YUNIS, 1996, p. 64-5), e é a partir desse recorte que se desenvolverá a análise proposta.

\section{Apesar dos transtornos ocasionados pela guerra e a peste, os meios de comunicação entre Péricles e seus concidadãos não foram destruídos, e ele soube aproveitá-los bem}

O acesso à assembleia ateniense era um meio pelo qual Péricles poderia falar a um número considerável de cidadãos ao mesmo tempo. Ele entendia claramente isso e não perdeu a oportunidade. Se Péricles não tivesse acesso a esse meio de comunicação, ou se esse meio tivesse sido dissolvido por causa das perturbações sociais ocorridas em Atenas, a persuasão seria um recurso impossível; pouco valeria a habilidade oratória de Péricles para conter a desordem pública. Estando ciente desse fato, ele tomou a seguinte decisão: "[Péricles], ao vê-los assim exasperados diante daquela situação e agindo exatamente como ele esperava, convocou uma reunião da assembleia - pois ainda era comandante $[. . .]^{\prime \prime}$ (Thuc., 2, 59, 3). 
A melhor forma de inibir um homem eloquente é impedi-lo de ter acesso aos meios de comunicação. Por outro lado, a melhor forma de incentivá-lo é disponibilizálos. O poder depende do controle dos meios de comunicação, e o contrapoder depende justamente em romper esse controle (CASTLELLS, 2010, p. 23).

Recorrendo-se à assembleia ateniense, Péricles utilizou um meio de comunicação cidadã e não um meio de comunicação em massa. Segundo Hohlfeldt (2001, p. 62), a expressão meios de comunicação em massa surgiu em conseqüência do processo de urbanização exponencial ocorrido, sobretudo, a partir da Revolução Industrial, o que tornou bastante difícil a participação e a comunicação direta e interpessoal entre os cidadãos no meio político, como ocorria de certa forma na assembleia ateniense, onde a participação era direta e não representativa (meios de comunicação cidadã). Com o fenômeno observado depois da Revolução Industrial, houve, então, a necessidade mais premente de "intermediários" entre as grandes populações e os fatos políticos, sobretudo por meio de tecnologias que veiculam as notícias dadas pelos representantes de vários setores da sociedade. Não era o caso de Péricles. Sua ação política entre os atenienses era efetivamente direta e sem intermediários.

\section{Péricles inspirava confiança por meio de um ethos à altura de sua ética}

Convocada a assembleia, Péricles principiou seu discurso nos seguintes termos:

Vossa irritação contra mim não me surpreende, pois conheço suas causas: ao convocar esta assembleia, meu propósito foi fazer-vos relembrar certos fatos e advertir-vos quanto à vossa atitude injustificada, seja demonstrando o vosso rancor contra mim, seja deixando-vos abater por vossas desventuras (Thuc., 2, 60, 1).

A cólera popular dos atenienses não era algo que poderia ser desconsiderado por Péricles. Aristóteles afirmou, na Retórica, que um exímio orador deve estar bastante atento aos ouvintes, sobretudo ao estado emocional deles:

Com efeito, o discurso comporta três elementos: o orador, o assunto de que fala, e o ouvinte: e o fim do discurso refere-se a este último, isto é, ao ouvinte [...]. Os fatos não se apresentam sob o mesmo prisma a quem ama e a quem odeia, nem iguais para o homem que está indignado e para o calmo, mas, ou são completamente diferentes ou diferem segundo critérios de grandeza (Arist., $R h$., 1378 a).

Perelman e Olbrechts-Tyteca (1996, p. 525) também chamam a atenção para isso, afirmando: 
O princípio capital, nessa matéria, continua a ser a adaptação ao auditório, às teses por ele admitidas, levando em conta a intensidade dessa adesão. Não basta escolher premissas nas quais se apoiar; cumpre prestar atenção, que uma vez a força do argumento se deve em grande parte à sua possível resistência às objeções, a tudo quanto o auditório admite, mesmo ao que não se tem nenhuma intenção de usar, mas que poderia vir opor-se à argumentação.

Diante disso, percebe-se que Péricles soube lidar não só com as objeções expressas verbalmente, mas também com as caladas e demonstráveis pelo comportamento dos ouvintes. Isso só é possível a partir da crença de que as pessoas com quem se fala são dotadas de uma racionalidade, em muitos aspectos, semelhante a de si próprio. Quando se tem a consciência da própria racionalidade e de seus mecanismos, e acredita-se que tais mecanismos são semelhantes aos dos ouvintes, o orador tem mais probabilidades de expressar o que está velado em seu auditório e afastar tudo aquilo que impeça a persuasão do mesmo (PERELMAN; OLBRECHTS-TYTECA, 1996, p. 37; 525; 566). Naquelas circunstâncias, não bastaria a Péricles ser honesto e confiável; também seria necessário que ele falasse de tal maneira que a maioria das pessoas o percebesse assim, como aconselha Aristóteles no seguinte excerto:

Três são as causas que tornam persuasivos os oradores e a sua importância é tal que por elas nos persuadimos, sem necessidade de demonstrações. São elas a prudência, a virtude e a benevolência. [...] forçoso é, pois, que aquele que aparenta possuir todas estas qualidades inspire confiança nos que o ouvem (Arist., Rh., 1378 a).

Quanto mais desconhecido for o orador ao seu auditório, mais será sua preocupação em projetar essa imagem digna de confiança aos seus ouvintes; o que não era o caso de Péricles. Pois este já granjeara, segundo Tucídides, a fama de homem honesto e confiável: "a razão do prestígio de Péricles era o fato de sua autoridade resultar da consideração de que gozava e de suas qualidades de espírito, além de uma admirável integridade moral" (Thuc., 2, 65, 8). Plutarco concorda com a opinião de Tucídides nesse aspecto (Plut., Per., 15.2). No entanto, as adversidades pelas quais os atenienses passavam provavelmente anuviaram tal reputação: "sentindo-se no limite de seu desespero, intensificavam suas acusações contra Péricles" (Thuc., 2, 59, 2). Assim, a preocupação com sua reputação não seria algo a ser desprezado pelo político ateniense. $E$, de fato, sabemos que um de seus propósitos era afastar o ressentimento do povo ateniense sobre sua pessoa (Thuc., 2, 59, 3).

Nesse sentido, paradoxalmente a situação de Péricles se torna ainda mais delicada quando se considera a fama de exímio orador que já possuía em seu tempo (Thuc., 1, 139, $4 ; 2,34,6-8$ ). Cientes de sua habilidade oratória, os ouvintes provavelmente poderiam 
assumir uma postura desconfiada em relação a ele, devido ao provável receio de serem seduzidos e enganados acerca dos problemas que enfrentavam naquele momento. Aliás, até mesmo seus próprios inimigos políticos reconheciam seu talento oratório. Plutarco, por exemplo, afirma que certa vez Arquidamo, rei de Esparta, perguntou a Tucídides (não o historiador, filho de Oloros, mas o político, filho de Melésias) se era ele ou Péricles quem combatia melhor. Tucídides respondeu: "Quando eu o derrubo em combate, ele nega ter caído e leva a melhor, pois altera a opinião de quem assiste" (Plut., Per., 8, 5). É provável que Péricles tenha percebido esse tipo de desconfiança em seu auditório. E talvez por isso evitou floreios, figuras extravagantes ou frases de efeito no início de seu discurso. Ele foi direto: "vossa irritação contra mim não me surpreende, pois conheço suas causas". ${ }^{11}$

Ao afirmar isso, Péricles já está construindo seu ethos discursivamente: a do político previdente. Quando toma a iniciativa de convocar a assembleia, ele também projeta a imagem de líder corajoso, que preza pela transparência na condução da política. Isso enfraqueceria a possível desconfiança de que ele fosse um manipulador insensível frente aos problemas de seus concidadãos

\section{Péricles sabia lidar com o sistema de valores de seus ouvintes usando recursos dedutivos e indutivos}

Eis o primeiro argumento usado por Péricles para justificar a opinião de que a atitude dos atenienses era inadequada: "Na minha opinião, uma cidade proporciona maiores benefícios aos seus habitantes quando é bem-sucedida como um todo do que quando seus cidadãos prosperam individualmente, mas fracassam como uma comunidade" (Thuc., $2,60,2-3)$

Péricles irá construir um entimema, ou seja, um silogismo retórico. Segundo Aristóteles, o entimema é um raciocínio que não parte de um axioma (premissa que possui um grau de confiabilidade maior, como por exemplo: "todo homem é mortal"), mas sim de uma opinião provável que nem todos aderem imediatamente. Sobre este ponto, Aristóteles afirma:

O entimema é uma espécie de silogismo, e que é do silogismo em todas as suas variantes que se ocupa a dialética, no seu todo ou nalguma de suas partes. É igualmente evidente que quem melhor puder teorizar sobre as premissas - do que e como se produz um silogismo - também será o mais hábil em entimemas,

\footnotetext{
${ }^{11}$ Acerca do estilo oratório de Péricles, Plutarco (Péricles, 5, 1) afirma que o discurso do estadista era "elevado e isento de vulgaridades e de ridicularias de mau tom; um rosto austero que não se abria a um sorriso; tranquilidade no andar e modéstia no vestir, que nunca se alteravam com a emoção dos discursos; a modulação da voz imperturbável; e outras tantas qualidades que causavam a todos admiração".
} 
porque sabe a que matérias se aplica o entimema e que diferença este tem dos silogismos lógicos. Pois é próprio de uma mesma faculdade discernir o verdadeiro e o verossímil [...]. E por isso, ser capaz de discernir sobre o plausível é ser igualmente capaz de discernir sobre a verdade (Arist., Rh., 1355 a).

A afirmação de Péricles que: "uma cidade proporciona maiores benefícios aos seus habitantes quando é bem-sucedida como um todo do que quando seus cidadãos prosperam individualmente, mas fracassam como comunidade" soaria muito bem ao senso comum, e por causa disso, raro seria quem a reprovasse abertamente, mesmo que houvesse muitas pessoas que não concordassem com ela em suas crenças mais profundas. No entanto, como visto anteriormente, persuadir alguém é muito mais do que despertar uma conivência a uma opinião expressa; mas sim, suscitar uma mudança de crença e ação (PLANTIN, 2018, p. 256). Para isso, a premissa de um entimema deve ser fortalecida durante a argumentação. E é isso que Péricles procura fazer ao utilizar um argumento hipotético de causa e efeito para justificá-la, ao dizer: "De fato, mesmo quando um homem é feliz em seus negócios privados, se a sua cidade se arruína, ele perece com ela; se, todavia, ele se encontra em má situação, mas se a cidade está próspera, é bem provável que ele conseguirá se recuperar" (Thuc., 2, 60, 3).

Tendo, assim, fortalecido sua premissa inicial, Péricles pode concluir o seguinte:

Portanto, se a cidade pode suportar o infortúnio de seus habitantes na vida privada, mas o indivíduo não pode resistir aos dela, todos certamente devem defendê-la, em vez de agir como fazeis agora propondo o sacrifício da segurança da comunidade por estar desesperados com as dificuldades que enfrentais internamente e adotando uma atitude crítica tanto em relação a mim, por vos haver aconselhado a entrar na guerra, quanto a vós mesmos, que votastes comigo a favor dela (Thuc., 2, 60, 4).

Agora veja-se outro interessante argumento utilizado por Péricles:

Na verdade, a altivez se dobra diante do súbito e insólito, e do que acontece contrariamente a todos os cálculos; tivestes exatamente essa experiência, não somente em outros assuntos, mas especialmente em relação à peste. Apesar de tudo, vós, que habitais uma grande cidade e fostes criados sob costumes compatíveis com sua grandeza, deveis suportar até as maiores calamidades em vez de desmerecer a vossa fama (Thuc., 2, 61, 3-4).

Péricles tenta fortalecer a afirmação feita do seguinte modo:

Todos se sentem no direito de detestar o homem que, por presunção, tenta conseguir uma reputação imerecida, da mesma forma que se julgam competentes para censurar aquele que, por lassidão, não se porta à altura da fama conquistada (Thuc., 2, 61, 3-4). 
Péricles apresenta nesse trecho dois tipos de pessoas que eram reprovadas pelo senso comum: a) o orgulhoso que tem uma fama imerecida; b) o desleixado que não se comporta de acordo com a fama alcançada. É como se Péricles voltasse um "espelho moral" contra eles e dissesse: "Vocês, atenienses, têm a fama de habitar uma grande cidade e de ter uma educação condizente com sua grandeza. Mas vejam! A maneira que vocês estão lidando com os sofrimentos presentes está condizente com sua fama?" Diante desse "espelho" habilmente elaborado por Péricles, os atenienses eram quase que constrangidos a responder a si mesmos: "Não. Estamos mais parecidos com um orgulhoso que tem uma fama imerecida ou com um desleixado que não se comporta a altura da fama conquistada". Depois de despertar tal sentimento de honra em seu auditório, Péricles então conclui o seu argumento: "É vosso dever, portanto, sobrepor-vos aos vossos sofrimentos individuais e devotar-vos à salvação coletiva" (Thuc., 2, 61, 4).

Na Retórica (1356 a), Aristóteles afirma que o orador persuade pelo seu caráter (ethos), pelo raciocínio (logos) e pela emoção (pathos). Nos trechos do discurso de Péricles até aqui analisados, foi possível ver o político ateniense agindo nessas três esferas.

\section{Péricles respeitava seus ouvintes como seres livres e dotados de racionalidade}

Péricles atesta:

[...] desesperados com as dificuldades que enfrentais internamente e adotando uma atitude crítica tanto em relação a mim, por vos haver aconselhado a entrar na guerra, quanto a vós mesmos que votastes comigo a favor dela (Thuc., 2, 60, 4).

Péricles qualifica a atitude dos atenienses como "injustificada" (Thuc., 2, 60, 1), indicando que eles não se mostravam fiéis a um pacto comum. Pois a decisão de entrar na guerra foi o resultado de um acordo, não de uma decisão arbitrária imposta por Péricles. Desta forma, o rancor não deveria ser direcionado somente a ele, mas sim "democratizado" entre todos os que com ele participaram nessa decisão. Péricles continua dizendo: "[...] eu o alvo de vossa ira, sou tão competente quanto qualquer homem, na minha opinião, para atinar com as medidas adequadas e expô-las" (Thuc., 2, 60, 5).

Ele não se coloca como uma pessoa superior, a ponto de exercer um poder irresistível sobre seus concidadãos, inibindo, assim, qualquer espaço para deliberação e escolha consciente acerca da guerra. Em vez disso, ele afirma que é "tão competente quanto qualquer homem". Não se pode esquecer, porém, que Péricles, além de ser um ilustre político 
(rhétor), também era um general (strathegós), e sua alta posição poderia causar um desnível acentuado entre ele e os outros, o que daria a seus discursos certo caráter coercitivo, mais que persuasivo. E, de fato, não seria algo impossível de acontecer (VOGT, 2009, p. 223-4), sobretudo antes da peste e da stásis reinante em Atenas. Todavia, nas circunstâncias em que o discurso em questão foi proferido, Péricles está mais sujeito a ser exilado ou condenado à morte do que propriamente retaliar alguém que não concorde com ele. Nada obstante, é justamente em situações tão adversas como essa que o brilhantismo de um orador e político democrático como Péricles teria mais chances de se manifestar.

Acerca de sua habilidade discursiva, Péricles declara: "aquele que elabora uma política e é incapaz de expô-la claramente aos outros está em pé de igualdade com quem jamais pôde concebê-la" (Thuc., 2, 60, 6).

Não saber expressar, segundo Péricles, é quase o mesmo que não poder conceber, pois a própria racionalidade está assentada na linguagem. Péricles expressa uma concepção bastante sofisticada sobre a relação que há entre linguagem e racionalidade. Será que Tucídides compartilhava a mesma opinião? Será que Péricles neste ponto está sendo uma espécie de porta-voz do autor da História da Guerra do Peloponeso? Talvez $\operatorname{sim}($ YUNIS, 1996, p. 61).

Desta forma, o Péricles tucididiano está dando a entender que a habilidade oratória é indispensável à vida política, e, por isso mesmo, ele não poderia ser censurado por ser detentor de algo imprescindível a qualquer cidadão que pretendesse se ocupar dos assuntos da pólis. Como visto, a verdadeira persuasão só existe quando não há ameaça de retaliação ou qualquer outro meio violento ou coercitivo para mudar as atitudes ou decisões de uma pessoa:

O uso da argumentação implica que se tenha renunciado a recorrer unicamente à força, que se dê apreço à adesão do interlocutor, obtida graças a uma persuasão racional, que este não seja tratado como objeto, mas que se apele à sua liberdade de juízo. O recurso à argumentação supõe o estabelecimento de uma comunidade dos espíritos que, enquanto dura, exclui o uso da violência (PERELMAN; TYTECA, 1996, p. 61).

Argumentar "significa considerar o outro como capaz de reagir e de interagir diante das propostas e teses que lhe são apresentadas" (MOSCA, 2001, p. 17). Tal consideração foi demonstrada por Péricles aos seus concidadãos: "Se, quando me permitistes persuadirvos a entrar na guerra, admitistes que, mesmo em grau moderado, eu possuía essas boas qualidades mais que outros, não é razoável que agora me acuseis de ser o culpado" (Thuc., 2, 60, 7). 


\title{
Conclusão
}

Segundo Tucídides, Péricles governou Atenas respeitando as normas democráticas de seu tempo, utilizando a persuasão ao invés da imposição. Entende-se que isso foi possível porque ele conseguia perceber e utilizar certas condições adequadas à persuasão, entendendo-a como um instrumento de ação política. Por outro lado, os atenienses utilizavam métodos impositivos e violentos em sua política externa, ou seja, quando se tratava das outras cidades gregas subjugadas ou neutras (COHEN, 1984). É o que afirma Cleão, político ateniense que alcançou projeção depois da morte de Péricles:

\begin{abstract}
Sois incapazes de ver que vosso império é uma tirania imposta a súditos que, por seu turno, conspiram contra vós e se submetem ao vosso comando contra a sua vontade, e vos obedecem não por causa de alguma generosidade vossa para com eles em detrimento de vossos interesses, mas por causa de vossa ascendência sobre eles, resultante de vossa força e não de sua boa vontade (Thuc., 3, 37, 3).
\end{abstract}

Não é de se estranhar. Pois onde não há o sentimento de igualdade e respeito mútuo instituído por um pacto, resta apenas o terreno fecundo para o mando, não para a força política que emana da persuasão.

\section{Referências}

\section{Documentação textual}

ARISTÓfANES. A Paz. Tradução de Maria de Fátima de Sousa e Silva. Coimbra: Instituto Nacional de Investigação Científica, 1984.

ARISTÓFANES. As Nuvens. Tradução de Mário da Gama Kury. Rio de Janeiro: Jorge Zahar, 1995.

ARISTÓFANES. Os Acarnenses. Tradução de Maria de Fátima de Sousa e Silva. Coimbra: Instituto Nacional de Investigação Científica, 1988.

ARISTÓTELES. Poética. Tradução de Eudoro de Souza. São Paulo: Abril Cultural, 1973.

ARISTÓTELES. Política. Tradução e notas de Maria Aparecida de Oliveira Silva. São Paulo:

Edipro, 2019.

ARISTÓTELES. Retórica. Tradução e notas de Manuele Alexandre Júnior, Paulo Farmhouse

Alberto e Abel do Nascimento Pena. Lisboa: Imprensa Nacional Casa da Moeda, 1998.

PLATÃO. Górgias. Tradução de Daniel R. N. Lopes. São Paulo: Perspectiva, 2016.

PLATÃO. O Banquete. Tradução de Carlos Alberto Nunes. Belém: Editora da UFPA, 2011. 
PLUTARCO. Vidas Paralelas: Péricles e Fábio Máximo. Tradução do grego, introdução e notas de Ana Maria Guedes Ferreira e Ália Rosa Conceição Rodrigues. Coimbra: Imprensa da Universidade de Coimbra, 2013.

SANTO AGOSTINHO. Confissões. Tradução de Lorenzo Mammi. São Paulo: Penguin, 2017.

\section{Obras de apoio}

AUSTIN, M.; NAQUET, P. V. Economia e sociedade na Grécia antiga. Lisboa: Edições 70, 1986.

CASTELLS, M. Comunicación y poder. Madrid: Alianza, 2010.

COHEN, D. Justice, interest, and political deliberation in Thucydides. Quaderni Urbinati di Cultura Classica, v. 16, n. 1, p. 35-60, 1984.

HOHLFELDT, A. Hipóteses contemporâneas de pesquisa em comunicação. In: FRANÇA, V;; HOHLFELDT, A.; MARTINHO, L. C. (org.). Teorias da comunicação: conceitos, escolas e tendências. Rio de Janeiro: Vozes, 2001.

LIDDEL, H. G.; SCOTT, R. Greek-English lexicon. Oxford: Clarendon Press, 1996.

LIDDELL HART, B. H. As grandes guerras da História. São Paulo: IBRASA, 1982.

MANUWALD, B. Diodotus' Deceit (On Thucydides 3.42-48). In: RUSTEN, J. S. (ed.). Oxford Readings in Classical Studies: Thucydides. Oxford: Oxford University Press, 2009, p. 241-260.

MOSCA, L. S. Velhas e novas retóricas: convergências e desdobramentos. In: MOSCA, L. S. (org.). Retóricas de ontem e de hoje. São Paulo: Humanitas, 2001.

MOSSÉ, C. As instituições gregas. Lisboa: Edições 70, 1985.

PERELMAN, C; OLBRECHTS-TYTECA, L. Tratado da argumentação. São Paulo: Martins Fontes, 1996.

PLANTIN, C. Não se trata de convencer, mas de conviver: a era pós-persuasão. Revista Eletrônica de Estudos Integrados do Discurso e Argumentação, n. 15, p. 244-269, 2018. RAAFLAUB, K. A. Ktema es aiei. Thucydides' concept of "learning through history" and its realization in his work. In: TSAKMAKIS, A.; TAMIOLAKI, M. (ed.). Thucydides between History and Literature. Berlin: De Gruyter, 2013, p. 3-21.

RIBEIRO FERREIRA, J. Participação e poder na democracia grega. Coimbra: Faculdade de Letras da Universidade de Coimbra, 1990.

RICOEUR, P. Temps et récit. Paris: Seuil, 1985.

RUSTEN, J. Pericles in Thucydides. In: JIMENEZ, A. P.; FERREIRA, J. R.; FIALHO, M. do C. (org.). O retrato literário e a biografia como estratégia de teorização política. Coimbra: Imprensa da Universidade de Coimbra, 2004. 
SANTOS, R. N. dos S. Retratos de um derrotado: Xerxes, o "Grande Rei". Codex, v. 8, n. 2, p. 171-182, 2020.

SOARES, M. T. M. 'Ekphrasis' e 'enargeia' na historiografia de Tucídides e no pensamento filosófico de Paul Ricoeur. Talia dixit, v. 6, p. 1-23, 2011.

TUCÍDIDES. História da Guerra do Peloponeso. Tradução e notas de Mario da Gama Kury. Brasília: Editora Universidade de Brasília, 1982.

VERNANT, J. P. As origens do pensamento grego. Rio de Janeiro: Difel, 2002.

VOGT, J. The portrait of Pericles in Thucydides. In: RUSTEN, J. S. (ed.). Oxford Readings in Classical Studies: Thucydides. Oxford University Press, 2009, pp. 220-237.

YUNIS, H. Taming democracy: models of political rhetoric in Classical Athens. Cornell: Cornell University Press, 1996. 